\title{
Prediction of secondary metabolite encoding genes based on chemical structure analysis
}

Petersen, Thomas Isbrandt; Nielsen, Maria Lund; Hoeck, Casper; Frandsen, Rasmus John Normand; Larsen, Thomas Ostenfeld

Published in:

Book of abstracts from the 13th European Conference on Fungal Genetics

Publication date:

2016

Document Version

Publisher's PDF, also known as Version of record

Link back to DTU Orbit

Citation $(A P A)$ :

Petersen, T. I., Nielsen, M. L., Hoeck, C., Frandsen, R. J. N., \& Larsen, T. O. (2016). Prediction of secondary metabolite encoding genes based on chemical structure analysis. In Book of abstracts from the 13th European Conference on Fungal Genetics (pp. 458-458). [CS5T73]

\section{General rights}

Copyright and moral rights for the publications made accessible in the public portal are retained by the authors and/or other copyright owners and it is a condition of accessing publications that users recognise and abide by the legal requirements associated with these rights.

- Users may download and print one copy of any publication from the public portal for the purpose of private study or research.

- You may not further distribute the material or use it for any profit-making activity or commercial gain

- You may freely distribute the URL identifying the publication in the public portal 


\section{POSTER SESSION ABSTRACTS Session CS5 Applied genomics and biotechnology} CS5T73

Tuesday 5th April 14:00 - 16:00

ISBRANDT Thomas (1), LUND NIELSEN Maria (1), HOECK Casper (3), J. N. FRANDSEN Rasmus (2), O. LARSEN Thomas (1)

(1) Natural Product Discovery, Department of Systems Biology, Technical University of Denmark, Soltofts Plads, Lyngby, Denmark

(2) Eucaryotic Molecular Cell Biology, Department of Systems Biology, Technical University of Denmark, Lyngby, Denmark (3) Department of Chemistry, Technical University of Denmark, Kemitorvet, Lyngby, Denmark

\section{Prediction of secondary metabolite encoding genes based on chemical structure analysis}

Dereplication of the secondary metabolite profile from the filamentous fungus Aspergillus brasiliensis, by High Performance Liquid Chromatography coupled with Diode Array Detection and High Resolution Mass Spectrometry lead to the discovery of a novel biomarker having a unique UV spectrum and elemental composition. Structural elucidation based on Nuclear Magnetic Resonance spectroscopy of the pure compound revealed an apolar polyketide or fatty acid derived secondary metabolite, possibly assembled from two entities, a C8 and a C12 chain, fused via a Claisen-like condensation and subsequent cyclisation to form a core lactone ring structure. Despite the apolar nature of the compound initial bioassay investigation have demonstrated antibacterial activity against methicillin-resistant Staphylococcus aureus MB5393. The metabolite was also identified in strains of $A$. carbonarius and $A$. tubingensis, setting the scene for comparative bioinformatics analysis of the three genomes. Four candidate gene clusters have been selected for construction of knock out mutants using CRISPR/Cas9 in $A$. brasiliensis. This poster will summarize our efforts towards characterization of the biosynthetic pathway of this new compound that we have named brasenol. 